Kajian Malaysia, Vol. 37, No. 2, 2019, 1-20

\title{
THE UNIVERSITIES AND UNIVERSITY COLLEGES ACT IN MALAYSIA: HISTORY, CONTEXTS AND DEVELOPMENT
}

\author{
Wan, Chang Da
}

National Higher Education Research Institute, Universiti Sains Malaysia, Pulau Pinang, MALAYSIA

Email: changda.wan@usm.my

Published online: 20 November 2019

To cite this article: Wan, C.D. 2019. The Universities and University Colleges Act in Malaysia:History, contexts and development. Kajian Malaysia 37(2): 1-20. https://doi.org/10.21315km2019.37.2.1

To link to this article: https://doi.org/10.21315/km2019.37.2.1

\begin{abstract}
In Malaysia, Akta Universiti dan Kolej Universiti (AUKU) is the main legislation that governs public universities. It was enacted in 1971 and amended six times that had profound implications for the development of higher education, particularly on the governance and autonomy of public universities. However, the days of AUKU are numbered as the current Government in its election manifesto has slated for the act to be revoked and abolished. This paper examines the historical and chronological development of AUKU, more specifically the socio-politicaleconomic situation at the time of enactment and each subsequent amendment. In addition, the article also explores thematic issues related to AUKU, namely academic freedom and autonomy as well as the control of the State and Government on public universities.
\end{abstract}

Keywords: governance, legislation, autonomy, state-university relationship

\section{INTRODUCTION}

The Universities and University Colleges Act (UUCA 1971), known in Malay as the Akta Universiti dan Kolej Universiti (AUKU), is the main legislation that governs public universities in Malaysia. AUKU was enacted in 1971 and subsequently amended six times in 1971, 1975, 1983, 1996, 2009 and 2012. The enactment and each of the six amendments have all had profound implications for the development of higher education and of universities in Malaysia, particularly the governance of these public institutions, their degree of autonomy and the Stateuniversity relationship.

(C) Penerbit Universiti Sains Malaysia, 2019. This work is licensed under the terms of the Creative Commons Attribution (CC BY) (http://creativecommons.org/licenses/by/4.0/). 
This article fills a gap in the literature about this Act by exploring two essential contexts: first, the socio-political-economic situation in Malaysia at the time of the enactment and each subsequent amendment; and second, the debates in the House of Representatives leading towards the enactment and amendments. The focus on these two aspects, I would argue, provides a detailed understanding of the evolution of AUKU and its implications for the development of public universities in Malaysia.

In the recent run-up to the 14th General Election, in its manifesto the Pakatan Harapan coalition stated that AUKU is among the five laws explicitly slated to be revoked and abolished if the coalition was victorious. Indeed, the coalition won the 14th General Election and officially formed a Government on 11 May 2018. Hence, the days of AUKU are numbered, and a detailed and critical analysis of the history, contexts and development of this piece of legislation is imperative as Malaysia prepares more "comprehensive and better laws, [that] guarantee [a] high quality of education and academic freedom as well as freedom of speech and association" (Pakatan Harapan 2018, 106).

This article examines AUKU in two ways. The first reviews the historical and chronological development of AUKU through its enactment and amendments. The second focuses on two specific issues that are connected to AUKU: academic freedom and autonomy, and control from the State and Government.

\section{OVERVIEW OF HIGHER EDUCATION IN MALAYSIA}

Higher education in Malaysia is governed mainly by two major legislations. While AUKU governs public universities, private higher education institutions (which include universities, university colleges and colleges) are governed by the Private Higher Education Institutions Act 1996. Besides these two, there are eight other legislations which have direct and indirect relations to the development of higher education, which include: the Education Act 1961, the Companies Act 1965, the Universiti Teknologi MARA Act 1976, the National Higher Education Fund Corporation Act 1997, the National Higher Education Council Act 1996, the Statutory Bodies (Discipline and Surcharge) Act 2000, and the Malaysian Qualifications Agency Act 2007 (which replaces the National Accreditation Board Act 1996) (Zainal et al. 2013).

Higher education in Malaysia is generally divided into public and private sectors. The public higher education sector comprises 20 universities, 33 polytechnics and 91 community colleges, which are financially supported by the State through the Ministry of Education. ${ }^{1}$ In 2014, 560,000 students were enrolled in public universities, while 90,000 and 22,000 students were enrolled in polytechnics and community colleges respectively (Ministry of Education 2015). 
Conversely, the private higher education sector is made up of 70 universities, 34 university colleges and 410 colleges, with a total of 485,000 students enrolled across the three types of private higher education institutions.

\section{CHRONOLOGICAL DEVELOPMENT OF AUKU}

\section{Pre-AUKU}

Higher education in Malaysia began before the existence of AUKU, and the preAUKU period provides crucial comparative understanding of the subsequent developments after AUKU was enacted. Higher education began in Malaya while the country was still under the British administration. A commission, led by Sir William McLean, was appointed by the Secretary of State for the Colonies to survey the existing arrangements for higher education in Malaya in 1938, and the recommendation of the McLean Commission was to establish a university college by merging the King Edward VII College of Medicine and Raffles College (McLean Commission 1939).

However, the recommendation was disrupted by World War II; the four years of Japanese occupation in Malaya drastically changed the landscape of education in the country. Hence, after the war another commission, this time led by Sir Alexander Carr-Saunders, was set up in 1947 by the Secretary of State for the Colonies to re-assess the situation. The primary recommendation of the Carr-Saunders Commission was not only to merge the two colleges, but also to establish a full-fledged university instead of a university college (Carr-Saunders Commission 1948). Thus, in 1949 the University of Malaya was established in Singapore under the University of Malaya Ordinance 1949, and this marked the beginning of university education in Malaya.

In 1954 a proposal was put forward to set up an autonomous campus in Kuala Lumpur, in addition to the existing campus in Singapore. By 1962 the two campuses of the University of Malaya had become two separate universities. The campus in Singapore became the University of Singapore (later merged with Nanyang University to form the National University of Singapore), while the campus in Kuala Lumpur became the University of Malaya. The University of Malaya Ordinance was then replaced by the University of Malaya Act (1961), which became the major legal instrument for the governance of university education until the enactment of AUKU a decade later.

The University of Malaya was self-governing, with its own Constitution enacted in the University of Malaya Act (1961). Its governing structure mirrored a typical British university structure, including a Court, a Council, a Senate, Faculties, a Guild of Graduates, Boards of Studies, a Board of Selection and a 
Board of Student Welfare (Khoo 2005). Although the Court was seen as the highest authority in the university, in actual fact it was merely a formal and symbolic entity that linked the university and wider society through its broad representation, ranging from royalty, Government figures, captains of business and industry, distinguished citizens and foreign dignitaries from neighbouring countries.

The Council was the highest governing body of the university and was made up of elected representatives of the Senate, the Court and the Guild of Graduates. The Chairperson of the Council was elected by their peers within the Council. The Council was the principal authority on policy matters of the university, except for academic matters, and one of its key responsibilities was to appoint the Vice Chancellor, who was the principal academic and executive officer of the university. Academic matters were put under the purview of the Senate which was chaired by the Vice Chancellor.

Prior to AUKU, the University of Malaya was the only university in the country and was fully autonomous and self-governing based on its own Constitution - but interestingly it received significant financial support from the State. Between 1962 and 1969 the State provided $\$ 61.2$ million of the total $\$ 65.6$ million capital development expenditure of the university. In 1969 alone the annual recurrent expenditure of the university was $\$ 21.3$ million, of which $82.3 \%$ was borne by the State (Khoo 2005). The remaining recurrent expenditure was covered via tuition fees and rents of staff quarters, accounting for $13.7 \%$ and $4.0 \%$ respectively.

Although it received significant financial support from the State, the University of Malaya remained fully autonomous, as reflected by the fact that the Chairman of the Council of the University of Malaya was a leading opposition figure in Parliament. Known as "Mr Opposition", Dr Tan Chee Khoon was an alumnus of the university and was subsequently elected by the Guild of Graduates to serve on the Council. He reported in a parliamentary debate that he had been elected by his peers in the Council to assume the position of Chairman of the Council for a year and a half (Dewan Rakyat 8 April 1975, 4447-4448).

In addition, not only was "Mr Opposition" the Chairman of the Council, Dr M. K. Rajakumar, another renowned leftist intellectual who was seen to be anti-establishment at the time, was also a member of the Council representing the Guild of Graduates. Dr Rajakumar was a founding member of the infamous University of Malaya Socialist Club and was the editor of Fajar, a radical student newsletter produced by the club that was deemed seditious by the colonial authorities in Singapore in the late 1950s (Loh et al. 2012). He also famously led the opposition through the Labour Party of Malaya and Barisan Sosialis in the 1960s. Thus, the autonomy of the university was clearly reflected by the fact that these key individuals, who were politically and ideologically in opposition to the Government of the day, were allowed to lead and be part of the principal authority of the university, even though it was largely funded by the State. 
Following the recommendations of the Higher Education Planning Committee in 1967, a second Malaysian university was established in Penang. It was initially named the University of Penang, subsequently changed to Universiti Sains Malaysia. The Cabinet commissioned a committee in 1968 to draft a constitution for the new university. This committee was led by Mohamed Suffian, who was also involved in the drafting of the Constitution of Malaysia and who later became the Lord President of the Federal Court. Interestingly, the Suffian Report for the University of Penang began by outlining the important principles of university autonomy and academic freedom as fundamental to a university. The committee used the University of Malaya as the benchmark in its task, and recommended that the new university should be an autonomous body separate and apart from the Government (Suffian 1969). This therefore reaffirmed the fact that the University of Malaya was fully autonomous, with the Suffian Report on the University of Penang eloquently stating:

When an autonomous institution is mainly dependent for its income not on the fees of pupils, nor on private endowments, but on subventions from the State, how far should it have independent powers of initiative and final decision? Such a position of material dependence is in fact today the position of the University of Malaya. So far in the history of this country the activities of the University of Malaya have been remarkably immune from interference or control by the Government. Even though the growing financial needs of that University have increasingly made the Government the provider both of recurrent and of capital grants, exceptional care has been taken by Government to see that these subventions are made in a way that involves the minimum of interference with the policy of the University. ... It must, however, be said that in the determination of the aggregate amount to be spent from public funds, the Government necessarily has the last word and a wise university naturally wants to take into account the Government's responsibility for national development and for a fair and equitable distribution of the country's wealth among all sections of the community. Subject to this, we believe that academic freedom is a necessary condition of the highest efficiency and the proper progress of academic institutions, and that encroachments upon their liberty, in the supposed interest of greater efficiency, would in fact diminish their efficiency and stultify their development. (Suffian $1969,2)$

Furthermore, the Suffian Report for the University of Penang also spelt out four constituents of academic freedom and university autonomy in terms of appointments, curricula and standards and the admission of students, the balance between teaching and research, and salaries and staffing ratios. While the proposed Constitution of the University of Penang was largely similar to the Constitution of 
the University of Malaya, the articulation of the guiding principles of university autonomy and academic freedom by the committee underlined the importance of these concepts to ensure the Constitution fulfilled its mandate in upholding self-governance prior to the introduction of AUKU. The same committee led by Mohamed Suffian, with the exception of one member, also drafted the Constitution of the National University, which is Universiti Kebangsaan Malaysia.

\section{Enactment of AUKU}

The 13 May 1969 incident not only changed the social, political and economic fabric of Malaysia, but also left a deep impression in the development of higher education. Due to the racial rioting in Kuala Lumpur, a national state of emergency was declared and Parliament was suspended. Hence, universities were put under the jurisdiction of the Emergency (Essential Powers) Ordinance No. 74. This Emergency Ordinance then became the basis of AUKU, which was enacted in 1971.

The major rationale for the enactment of AUKU in 1971 was to provide a legal instrument for the establishment of universities in Malaysia, and to officiate the relationship between the State and universities. In tabling AUKU, the then Minister of Education, Hussein Onn, explained:

Universities anywhere in the world do not exist in a vacuum. Our universities, in particular, certainly do not. While the Government is in agreement with the concept of academic freedom, it is necessary however to remember always that like other freedoms it is not absolute. It is subject to qualifications imposed by national, financial and other practical considerations. In order to maintain its academic standards and thus ensure its repute in the international academic world a university will require vast amounts of public funds and in that process it will have to bear constantly in mind the national aspirations and needs as interpreted by the Government. (Dewan Rakyat 17 March 1971, 1401-1402)

While the University of Malaya has the University of Malaya Act 1961 as the legal basis for its existence, the Constitutions for the University of Penang and the National University that were drafted and circulated in 1971 were not tabled in Parliament. Instead, the two constitutions were absorbed as the Schedule within AUKU to form the template for a university constitution. As the Minister explained, AUKU provides the overarching legal instrument for establishing, maintaining and administering universities and university colleges, removing the requirement for a new act for each university or university college, as well as a separate Incorporation Order by the Yang di-Pertuan Agong for each institution (Dewan Rakyat 17 March 1971, 1402). Importantly, the provision of a template 
constitution such as the Schedule would also ensure similarity in the constitution of all universities.

Following the enactment of AUKU on 29 April 1971, the Act was amended several months later to incorporate minor additions such as increasing the composition of the University Senate to include deans, and requiring the audited accounts of universities to be tabled in both Dewan of Parliament instead of solely in the Dewan Rakyat. The amended AUKU came into force on 24 September 1971.

\section{The 1975 Amendment}

If AUKU marked the beginning of State intervention in universities, the amendment carried out in 1975 gave the State full control over universities (see UUCA 1975). The notable changes that were enacted in this amendment included the following (adapted from Wan 2017):

1. Sections 15 and 16 extended to allow the expulsion and suspension of individual students.

2. New Sections $16 \mathrm{~A}$ and $16 \mathrm{C}$ included disciplinary action and imposed punishment on academics, staff and employees.

3. Selection of student representatives through secret ballot.

4. Power to appoint the Vice Chancellor was taken away from the University Council and handed to the Yang di-Pertuan Agong acting on the advice of the Minister.

5. The Minister was tasked to appoint Deputy Vice Chancellors.

6. The Vice Chancellor was tasked to appoint Deans, Deputy Deans and Heads of Institutes or Schools, replacing democratic elections among academics.

7. University Council was restructured to comprise five high-ranking Government officials and other representatives appointed by the Minister. No representation from the Guild of Graduates or the Senate. The Minister was also tasked to appoint the Chairman of the University Council instead of him being elected in an internal election within the Council.

Arguably, the 1975 Amendment was the most significant change to AUKU in terms of tightening control over universities by the State. Not only did the control of students became more elaborate, this control was also extended to academics. In addition, the self-governing capabilities of universities were taken 
away and transferred to the State. The Minister assumed a powerful position with the ability to unilaterally determine the important leadership appointments of a university.

However, the contexts surrounding this amendment need to be examined more critically and carefully. Since the enactment of AUKU in 1971 student activism has not been curbed, but instead has intensified significantly. Historically, student activism in the 1940s and 1950s was nationalistic in nature, aligning to the anti-colonial movement and fighting for the independence of the country. The year 1967 was argued to be the distinguishing year following the Teluk Gong incident, when student activism shifted from nationalistic concerns to local problems of rural poverty, landlessness and land hunger (Hassan 1984). The Teluk Gong incident was a dispute over land between the landless villagers of Teluk Gong and the Government. Mass protests by university students continued and intensified after AUKU with the Tasek Utara and Baling incidents (see Hassan 1984; Musa 2016). Specifically in terms of the Baling incident, two student-led demonstrations were held involving more than 30,000 people in Baling and 5,000 in Kuala Lumpur on 1 and 3 December 1974 respectively, and for the first time police went onto the three university campuses and arrested 1,128 students (and a handful of academics). Hence, student activism played a huge part in motivating the 1975 Amendment, and the then Minister of Education, Mahathir Mohamed, stated the following in Parliament while tabling the amendment:

Nowhere in the country have there been such goings-on as found in the universities. Students take over the campus and expel university authorities. Massive quantities of libellous documents and papers are produced in the universities and disseminated throughout the country. Day in and day out public money is wasted as students demonstrate and make speeches while lecture halls are deserted. Plans are made to disrupt life in the campuses and outside them and are carried out persistently with impunity. (Dewan Rakyat 8 April 1975, 4399)

This "disruptive" student activism was linked to Communism as the main enemy of the State and Islam at that time by the then Minister of Education in his parliamentary debates (Dewan Rakyat 8 April 1975). Student activism was equated to an act of sabotage and treachery against the nation, and therefore the Government felt it had a duty to protect society's and the universities' interests by amending AUKU. The Minister of Education claimed that pockets of students were disrupting education through protests, instigating other students to become involved in their speeches, and indoctrinating new students through university orientation programmes to instil a need to fight for perceived injustices in society.

More controversially, these disruptions to education were claimed to be a form of sabotage of the New Economic Policy (NEP). The NEP was the 
socio-economic policy introduced after the racial riots to address the imbalance between ethnic groups. The Minister argued that the most serious impact of these disruptions was on Bumiputera students, who were seen as the weakest academically, hindering them from making full use of the opportunity to improve their lives through university education.

In retrospect, while the student activism situation may justify the amendments tightening the control of students, nevertheless a large proportion of the 1975 Amendments was aimed at dismantling the self-governance and independence of universities. In other words, this amendment provided the means for the Government to intervene directly into the governance of universities, and universities lost a significant amount of autonomy. Was this loss of autonomy a punishment meted out on universities for their perceived failure to control their students? Or was the disruption a convenient excuse for the Government to wrest control back from the self-governing universities?

There was a minor amendment in 1983 (see UUCA 1983), where Section 5 was amended to loosen the prohibition on establishing universities in preparation for the establishment of the International Islamic University Malaysia under the Companies Act instead of AUKU.

\section{The 1996 Amendment}

The 1996 Amendment was another major milestone in the development of AUKU. The deliberation to amend AUKU again was tabled in Parliament in December 1995, and the amendment came into force in October 1996 (UUCA 1996). The 1996 Amendment brought about another significant restructuring of Malaysian universities, particularly in terms of corporatising their governance (Lee 2004; Wan and Morshidi 2018). Among the notable changes resulting from the 1996 Amendment were (adapted from Wan 2017):

1. Power to appoint the Vice Chancellor was transferred from the Yang diPertuan Agong to the Minister.

2. The University Council became the Board of Directors. Sixteen representatives were reduced to eight, and all representatives on the board were appointed by the Minister.

3. The University Senate was downsized from including all professors and deans (200-300 members depending on the university) to only including institutional leaders and not more than 20 professors, to be appointed by the Vice Chancellor. 
Wan, Chang Da

The 1996 Amendment was initiated to provide a framework for the corporatisation of public universities. ${ }^{2}$ The restructuring of the highest governing body of the university, from a council to a board of directors, illustrates the changing discourse and the replacement of terms from academe with those from corporate governance. The reduced composition of the Board of Directors to only eight representatives was also meant to be more in line with the corporate practice of having a lean governing body.

The most impactful change resulting from the 1996 Amendment was the downsizing of the University Senate, which effectively gagged the academic voice in universities. Not only had the numbers of professors been reduced in the highest academic body in a university; even these small representations had to be appointed by the Vice Chancellor. As may be expected, professors who were vocal and critical of the administration of the university or the Government would not be appointed, and the restructuring of the Senate therefore seriously undermined the authority and independence of academics in a university. Detrimentally, the restructuring consolidated authority in the hands of a single individual, the Vice Chancellor, who not only chairs the Senate and appoints institutional leaders (as provided in the 1975 amendments), but also appoints all other representatives in the Senate. In other words, the authority of the Vice Chancellor on academic matters was made absolute in the 1996 Amendment.

In addition to the intended purpose of making changes to universities, the global and national economic context also played a big role in shaping this amendment. Since the early 1990s, corporatisation and privatisation of higher education has been the global trend. Earlier in the decade, the United Kingdom and Australia began to charge full tuition fees for international students, as well as subsidised tuition fees for domestic students. The economic ideology of neoliberalism that coexisted with concepts of New Public Management, accountability, delivery and efficiency gradually seeped into the vocabulary of university governance (see Besosa 2007; Morshidi 2010; Sporn 2005). Hence, corporatisation, marketisation and privatisation in higher education were taking place globally, particularly in developed higher education systems.

Economically, the early to mid-1990s was a boom period as the Malaysian economy recovered from the recession of the 1980s. Economic growth has increased the expectation and demand for higher education. Particularly with the non-Bumiputera middle class, access to public universities has been challenging due to the ethnic quota, and the alternative was to send their children abroad. Not wanting to disrupt the ethnic quota in public universities but at the same time with the intention to increase access to higher education domestically, the Government legalised the existence of private higher education institutions (Mahathir Mohamed, pers. comm., 19 July 2016). This led to the tabling of the Private Higher Education Institutions Act 1996, and along with the liberalisation of the higher education 
sector several other legislations were also tabled during the same period. These legislations included the National Higher Education Fund Corporation Act 1997, the National Higher Education Council Act 1996 and the National Accreditation Board Act 1996.

The political-economic ideology at that time was to privatise key sectors as part of economic reform. Public utilities and national industries such as the postal services, energy supply and telecommunications were privatised through multiple forms of divestment of public ownership (Gomez and Jomo 1997). The aim was to deregulate the economy, reduce State intervention and curb State funding. Higher education was not spared from this structural reform. Hence, in 1996 the concurrent legalisation of private higher education institutions and corporatisation of public universities exemplified the political-economic ideology of privatisation undertaken by the Government.

However, while the 1996 Amendment of AUKU may have intended to reduce the dependence of public universities on State funding, the reality is that this amendment has resulted in a loss of academic voice in universities, and strengthened the Government's ability to intervene directly, not only in terms of governance but also regarding the academic matters affecting the university. As Morshidi (2010) claimed, while Government had exerted control over universities through budgetary, financial regulations and student intakes since the 1970s and 1980s, their core academic and institutional autonomy was completely stripped away in the 1990s, and the 1996 Amendment of AUKU played a big enabling role in this.

\section{The 2009 and 2012 Amendments}

AUKU was further amended in 2009 and 2012. These two amendments, although not as drastic as the previous ones, deserve to be examined along with the contexts that led up to them. Among the significant changes from the 2009 amendment were (adapted from Shad Saleem 2019):

1. Establishing a "search" committee to advise the Minister on the appointment of leadership positions in universities.

2. Authority given to the Minister to second or transfer a university employee.

3. Authority to control students shifted from the Minister to the university.

4. Criminal penalties in AUKU were abolished and student discipline was decriminalised.

5. The authority to discipline academics, staff and employees of the university was abolished. 
6. Establishment of a "campus" of a university in or outside of Malaysia was provided for.

7. A representative from the Senate on the Board of Directors was reintroduced.

8. A Management Committee of the University was introduced.

The 2009 Amendment was initiated after the Ministry of Higher Education launched the National Higher Education Strategic Plan 2007-2020 (PSPTN). One of the underpinning discourses at this point was that universities need a greater level of autonomy and accountability to compete with the very best institutions globally. The PSPTN clearly emphasised autonomy as necessary to attract and retain talent, advance research and develop competitive graduates. Hence, the provision to set up a search committee to advise the Minister on appointments, empowering universities and providing a voice for academics from the Senate to sit on the Board of Directors, collectively underlined the aspiration of the Government to give some degree of autonomy back to universities. The developments in autonomy following the 2009 amendment will be discussed in the next section of the article.

At a by-election in April 2010, four students from a public university were arrested by police and disciplinary proceedings were initiated by the university under Section 15(5)(a). Although they were found not guilty by the university, they sought a court declaration that Section 15(5)(a) of AUKU contradicted Article 119 of the Federal Constitution, which states that every citizen over the age of 21 is qualified to vote, which implies expression and participation in politics. However, in this particular section AUKU forbids expressing support for political parties and participating in politics. The High Court declared the restrictions were constitutional, but this decision was overturned by the Court of Appeal by a majority decision on 31 October 2011, meaning that this particular section of AUKU is unconstitutional and violates freedom of expression (The Star 2011).

This landmark decision of the Court of Appeal therefore became the basis for the 2012 amendment. The major change in AUKU was mainly to relax the limit concerning control over students' participation in politics on campus, and alongside this change were two administrative amendments:

1. Making the position of Director General of Higher Education formal within the administration of higher education.

2. Introducing the National Higher Education Register under the charge of the Director General. 


\section{THEMATIC ISSUES OF AUKU}

Having examined the chronological development of AUKU, specifically its history and social-political-economic contexts, the focus of the paper is shifted to the two major recurring themes associated with AUKU: academic freedom and autonomy, and control by the State and Government.

\section{Academic Freedom and Autonomy}

Academic freedom and university autonomy are two interrelated and inseparable concepts. In its 1997 Recommendation concerning the Status of Higher Education Teaching Personnel, UNESCO (1997) defines academic freedom as:

The right, without constriction by prescribed doctrine, to freedom of teaching and discussion, freedom in carrying out research and disseminating and publishing the results thereof, freedom to express freely their opinion about the institution or system in which they work, freedom from institutional censorship and freedom to participate in professional or representative academic bodies.

In other words, an academic has the freedom to conduct research, teach, speak and publish about their subject to the norms and standards of scholarly enquiry without external interference in the search for truth and understanding.

University autonomy, on the other hand, refers to the degree of selfgovernance of the institution and the institutional form of academic freedom. Importantly, university autonomy is the "necessary precondition to guarantee the proper fulfilment of the functions entrusted to teaching personnel and institutions" (UNESCO 1997).

AUKU has been the instrument used by the Government to restrict institutional autonomy, although the initial draft of the legislation was meant to provide a legal framework for establishing universities. As the Minister assured in 1971 while tabling AUKU:

Mr Speaker, Sir, a university established under this Bill will be an autonomous body and apart from the Government. It will be a body corporate with perpetual succession and with specific powers as mentioned in Clause 7 of the Bill. (Dewan Rakyat 18 March 1971, 1467)

However, the subsequent amendments deviated from the original intention. First, the 1975 Amendments dismantled the self-governance capabilities of universities by restructuring the University Council and removing the democratic structure comprising diverse representation of stakeholders including academics 
and alumni. Second, the 1996 amendment completely wiped out the influence of academics by downsizing the Senate, as well as further streamlining governance under the pretext of corporatisation. Collectively, therefore, these two major amendments significantly reduced the degree of self-governance and provided avenues for intervention into the governance of universities by external parties, notably the Minister and bureaucrats from Governmental agencies.

Given the fact that university autonomy was removed through legislation, the restoration of university autonomy should have been accompanied by legislative reform. This may include repealing or revising AUKU by "undoing" the 1975 and 1996 amendments. Despite the fact that successive Ministers of Education/Higher Education have gradually awarded autonomous status to all 20 public universities from 2012 up to the present, this has not been accompanied by legislative and structural changes in terms of human resources, financial procedures or the appointment of leaders of these universities (see Fauziah and Ng 2015; Soaib and Sufean 2012; Siti Naaishah, Shad Saleem Faruqi and Nazura 2009; Wan 2017; Wan and Abdul Razak 2015). Hence, with the current AUKU in place, public universities remained less autonomous as compared to the institutions that existed before 1975.

The lack of university autonomy suggested that academic freedom would also be limited. Section 16A in particular, which was added in 1975, has been seen as the main hindrance to academic freedom in AUKU. However, this Section was repealed in the 2009 amendments, and control over academics, staff and employees of the university was detached from AUKU. Although AUKU currently does not have direct control over academics, the status of a public university as a federal statutory body therefore implies that all academics and employees of the university are subject to the Statutory Bodies (Discipline and Surcharge) Act 2000. Furthermore, due to the fact that public universities subscribe to the human resource framework of the Public Service Department, academics and employees university are also subject to some of the instructions and rules meant for civil service employees, such as the need for permission to travel outside Malaysia for official purposes such as attending conferences or presenting a paper; this requires permission not only from the Vice Chancellor and Chairman of the Board of Directors, but also from the Chief Secretary of the Ministry of Education.

\section{Control by the State and Government}

Historically, given that AUKU was developed with minor amendments from the Emergency Ordinance No. 74, a strong element of "control" and "maintaining order" was incorporated into the inaugural draft of AUKU. The "notorious" Sections 15 and 16 of AUKU, which outlined prohibitions on students' activities and the power of the University Council in relation to student organisations, 
received strong objections from students and the academic community in universities even prior to AUKU's enactment in 1971. Yet it is important to point out that the provision of Section 15 in AUKU 1971 prohibited student councils and organisations from developing affiliations with political parties or trade unions (Clause 15.1), while individual students were prohibited from becoming office holders in political parties or trade unions (Clause 15.2). Particularly for the prohibition in Section 15.1, the justification was that student organisations in universities were not subject to the Societies Act and other laws of the land, and therefore had to be included in AUKU to safeguard against infiltration by negative elements. The Minister also reaffirmed:

All these, however, do not prevent students in their individual capacity from having or expounding their political views. This, Mr Speaker, I wish to make absolutely clear. This does not, however, prevent students in their individual capacity from having or expounding their personal political views. (Dewan Rakyat 18 March 1971, 1465-1466)

While the control was mainly focused on student councils and organisations in the initial Act in 1971, this control was narrowed down to individual students beginning with the 1975 amendment. AUKU also spelt out terms of criminalisation for political behaviour through punishment and penalties for violating the law, and political behaviour was only decriminalised in AUKU from the 2009 amendment onwards. Specifically in term of control over politics, the 2012 amendment restricted political involvement only on campus, and students are now free to participate in politics and express their political support and affiliations outside campus.

Besides control over students, the amendments to AUKU over the years have given authority to the Government to exert strong and direct control over universities, most clearly illustrated through the powers of the Minister in the appointment of key leadership positions in these institutions, namely the Vice Chancellor, Deputy Vice Chancellors, the Chairperson and members of the Board of Directors/Governors. The powers of the Minister have increased significantly from the initial AUKU, whereby the authority was only to investigate. The 1975 amendment empowered the Minister to appoint Deputy Vice Chancellors as well as have strong influence on the appointment of Vice Chancellors by advising the Yang di-Pertuan Agong. In the 1996 amendment the power to appoint Vice Chancellors was given solely to the Minister. Although a search committee was provided in the 2009 amendment to advise the Minister on the appointment of university leaders, the committee only exists to make recommendations and the authority remains firmly in the hands of the Minister.

The gradual concentration of power into the hands of the Minister was forewarned by the opposition when AUKU was tabled in 1971. In the debate to 
enact AUKU, a Member of Parliament who was also the Chairman of University of Malaya's Council suggested that the Minister should establish a University Grants Commission to provide some form of coordination of funding across universities and enable a more consistent funding stream:

... not on a year-to-year basis as it is now, but on a five year basis, so as to enable the Universities concerned to plan with greater assurance of funds that will be forthcoming. (Dewan Rakyat 18 March 1971, 1488)

Having an independent Commission to disperse public monies provided some forms of checks and balances on the role of the Minister in terms of funding for universities. Further analysis of the amendments to AUKU illustrate the crudeness displayed by the Government in "bulldozing" through these proposed changes. For instance, the debates on the 1975 Amendment only lasted five hours in Dewan Rakyat, despite attempts to table additional motions to counter-amend AUKU being raised by the opposition. The debates on the 1996 Amendment were even shorter, only lasting two hours for the Second, Committee and Third Readings.

\section{WHAT NEXT FOR AUKU?}

Now that the political party that advocated the repeal of AUKU has become the Government and the repeal has clearly been stated as part of their manifesto, it is expected that a major reform on the governance and legislation of higher education will take place. There are several possible scenarios that the Government may consider in relation to AUKU.

First, if AUKU is to be repealed, there is a need for a replacement legislation to provide a legal framework for public universities. While the sentiment expressed in the manifesto advocating the repeal of AUKU was that this is a highly repressive legislation, in fact, the "repressiveness" can only be attributed to Sections 15 and 16 in the earlier versions, as well as the consolidation of authority into the hands of the Minister of Education. It is crucial to note that AUKU is the source of legal authority for the existence of 18 of the 20 public universities. ${ }^{3}$ Thus, a replacement in the form of another overarching legislation like AUKU has to be put in place, or every public university will require a separate act on its own as a legal basis for existence, such as University of Malaya Act before AUKU was enacted. The former option of having one replacement Act is the more practical solution, avoiding drastic disruption to legislation.

However, if having one overarching replacement act is considered, this initiative also presents an opportunity for a more thorough legislative reform in higher education. The Report by the Committee to Study, Review and Make 
Recommendations Concerning the Development and Direction of Higher Education in Malaysia, more fondly known as the Wan Zahid Report, has outlined that the AUKU has not been comprehensive to cover the different roles undertaken by universities (Ministry of Higher Education 2006). Other crucial academic matters, such as study programmes, qualifications of academics, teaching permits, research, quality assurance and standards, are not covered in AUKU. Also, as mentioned earlier, there are eight legislations that directly and indirectly relate to higher education, and the separation of AUKU and Act 555 has been a major factor in separating the Malaysian higher education system into two different terrains. Hence, this therefore may be an opportune time to consolidate the various legislations and develop a comprehensive and consolidated legislation for the entire higher education system of Malaysia covering public and private higher education institutions.

Second, if the Government is serious about the autonomy of universities, the initiative to repeal AUKU or replace it with a similar act provides an opportunity to restore the self-governing capabilities of universities. The pre-AUKU University of Malaya before 1971 could serve as the basis to put in place the structure for individual public universities to govern themselves without interference from external parties, including the Government and minister. Furthermore, the Autonomous Universities Act in neighbouring countries like Indonesia and Thailand which have legislatively enacted the concept of autonomous universities (see Lao 2019; Pannen, Wirakartakusumah and Subhan 2019), could also serve as reference point for awarding autonomous status to universities and have the rights and responsibilities of all parties outlined in the law. Another good practice to consider is the case of New Zealand where all public universities are autonomous, and the law clearly outlines a collective governance structure that is not dominated by one party, be it the Government, bureaucrats or university community. The idea of an autonomous university is therefore for the university to determine its own direction and course of development, and not to be waiting for allocation and directive from an external party.

Apart from restoring self-governing capabilities to ensure autonomy of universities, the enactment of new legislation for higher education further presents an avenue to create a buffer body in the national governing structure. The idea of a University Grants Commission has been a common structure used to detach the governance of universities away from the Government and bureaucrats, by placing it in the hands of subject matter experts within the Commission. The structure of having independent buffer body(ies) or Commission(s), although not necessarily having the word "Commission" in its name, to govern the national higher education system has been practiced in the United Kingdom, Hong Kong, New Zealand, India, Thailand and the Philippines with some degree of variations. However, the commonality is to put the governing, disbursing of public monies and monitoring into the hands of a collective group of subject matter experts. 


\section{CONCLUSION}

AUKU has served the higher education of Malaysia for more than five decades. What began as an Act to provide legal authority to establish universities has developed and changed its course in line with social, political and economic developments of the country, by heavily influencing the governance of universities and control over students and academics. In the end, AUKU has been perceived to be a hindrance to the progress of universities and their autonomy as well as to academic freedom, but in all fairness AUKU still has an important role in providing legal authority for public universities to exist and operate in Malaysia. It is perhaps the opportune moment to revisit the legislation of higher education as a whole as well as the governance of higher education institutions at both the system and institutional levels.

\section{AUTHOR'S NOTE}

This article has been accepted for publication on 27 January 2019, before the author's appointment to a consultancy project for the Ministry of Education involving AUKU, in March 2019.

\section{NOTES}

1. Higher education was under the jurisdiction of the Ministry of Higher Education between 2003-2013 and 2015-2018. When the Ministry of Higher Education ceased to exist, higher education was placed under the Ministry of Education.

2. From this point onwards, private universities could be legally established following the enactment of the Private Higher Education Institutions Act (Act 555) 1996. For clarification, the term "university" in this article will continue to refer to public universities established under AUKU, and "private university" to refer to institutions established under Act 555.

3. International Islamic University Malaysia was established under the Companies Act and Universiti Teknologi MARA has its own act; but these two are also considered public universities as they do receive public monies.

\section{REFERENCES}

Besosa, M. 2007. Golden state solidarity. Academe 93(3): 40-44. https://doi.org/10.1016/ S1097-8690(07)70673-X

Carr-Saunders Commission. 1948. Report of the Commission on University Education in Malaya. Kuala Lumpur: The Government Press. 
Dewan Rakyat. 1971. Official Report, House of Representatives, Third Parliament, First Session Vol. I, No. 14, 17 March. . 1971. Official Report, House of Representatives, Third Parliament, First Session Vol. I, No. 15, 18 March. 1975. Parliamentary Debates, Fourth Parliament, First Session Vol. I, No. 40, 8 April.

Fauziah, M.T. and M.L.Y.A. Ng, eds. 2015. Governance reforms in public universities of Malaysia. Penang: Universiti Sains Malaysia Press.

Gomez, E.T. and Jomo. 1997. Malaysia's political economy: Politics, patronage and profits. Cambridge: Cambridge University Press.

Hansard DR Deb I/14 (17 March 1971). [Electronic version].

Hansard DR Deb I/15 (18 March 1971). [Electronic version].

Hansard DR Deb I/40 (8 April 1975). [Electronic version].

Hassan Karim. 1984. The student movement in Malaysia, 1967-1974. In With the people!: The Malaysian student movement, 1967-74, eds. Karim Nor Hamid, 1-26. Petaling Jaya: INSAN.

Khoo, K.K. 2005. 100 Years: The University of Malaya. Kuala Lumpur: Universiti Malaya Press.

Lao, R. 2019. Governance and management of universities in Thailand. In The governance and management of universities in Asia: Global influences and local responses, eds. C.D. Wan, M.N.N. Lee and H.Y. Loke, 1-26. Oxfordshire: Routledge. https://doi.org/10.4324/9780429427831-10

Lee, M.N.N. 2004. Restructuring higher education in Malaysia. Penang: School of Educational Studies, Universiti Sains Malaysia.

Loh, K.S., E. Liao, C.T. Lim and G.Q. Seng. 2012. The university socialist club and the contest for Malaya: Tangled strands of modernity. Amsterdam: Amsterdam University Press. https://doi.org/10.2307/j.ctt46n1s0

McLean Commission. 1939. Higher education in Malaya: Report of the Commission appointed by the Secretary of State for the Colonies. London: Colonial Office.

Ministry of Education (MOE). 2015. Malaysia education blueprint (higher education) 2015-2025. Putrajaya: Ministry of Education Malaysia.

Ministry of Higher Education (MOHE). 2006. Report by the Committee to study, review and make recommendations concerning the development and direction of higher education in Malaysia. Shah Alam: Universiti Teknologi MARA Publication Centre.

Morshidi Sirat. 2010. Strategic planning directions of Malaysia's higher education: University autonomy in the midst of political uncertainties. Higher Education 59: 461-473. https://doi.org/10.1007/s10734-009-9259-0

Musa Hitam. 2016. Frankly speaking. Subang Jaya: Pelanduk.

Pakatan Harapan. 2018. Buku harapan: Rebuilding our nation, fulfilling our hopes. Putrajaya: Pakatan Harapan.

Pannen, P., A. Wirakartakusumah and H. Subhan. 2019. Autonomous higher education institutions in Indonesia: Challenges and potentials. In The governance and management of universities in Asia: Global influences and local responses, eds. C.D. Wan, M.N.N. Lee and H.Y. Loke, 56-80. Oxfordshire: Routledge. https:// doi.org/10.4324/9780429427831-5 
Wan, Chang Da

Shad Saleem Faruqi. 2019. Public universities: Autonomy and the law. In Higher education in Malaysia: A critical review of the past and present for the future, eds. C.D. Wan, Morshidi Sirat and Dzulkifli Abdul Razak, 295-305. Penang: Universiti Sains Malaysia Press and Nilai: Universiti Sains Islam Malaysia Press.

Siti Naaishah Hambali, Shad Saleem Faruqi and Nazura Abdul Manan. 2009. The development of education law relating to the public universities in Malaysia: Towards liberalisation of the university governance and commercialisation of the academic activities. Paper presented at the 10th General Assembly of ASEAN Law Association, Hanoi, Vietnam, 1-18 October.

Soaib Asimiran and Sufean Hussin. 2012. University governance: Trends and models. Kuala Lumpur: University of Malaya Press.

Sporn, B. 2005. Convergence or divergence in international higher education policy: Lessons for Europe. https://net.educause.edu/ir/library/pdf/ffpfp0305.pdf (accessed 15 May 2015).

Suffian, M. 1969. Report of the Cabinet Committee on the Constitution of the University of Penang. Kuala Lumpur: Jabatan Chetak Kerajaan.

The Star. 2011. Court rules AUKU Section 15(5)(a) violates freedom of expression. 31 October.

UNESCO. 1997. Recommendation concerning the status of higher-education teaching personnel. http://portal.unesco.org/en/ev.php-URL_ID $=13144 \& U R L$ DO $=$ DO TOPIC\&URL_SECTION=201.html (accessed 23 July 2018).

Universities and University Colleges Act, Laws of Malaysia, Act 30 (1971).

Universities and University Colleges (Amendment) Act, Laws of Malaysia, Act 80 (1971). , Act 295 (1975). , Act 550 (1983). Act 946 (1996). , Act 1342 (2009). , Act 1433 (2012).

University of Malaya Act, Laws of Malaysia, Act 682 (1961).

Wan, C.D. 2017. The history of university autonomy in Malaysia. Policy IDEAS No. 40. Kuala Lumpur: Institute for Democracy and Economic Affairs.

Wan, C.D. and Abdul Razak Ahmad. 2015. Governance of higher education in Malaysia. In Global higher education: Issues in governance, eds. K.M. Joshi and S. Paivandi, 339-379. Delhi: B. R. Publishing.

Wan, C.D. and Morshidi Sirat. 2018. The evolution of corporatisation of public universities in Malaysia. In Higher education governance in East Asia: Transformations under neoliberalism, ed. J.C. Shin, 89-105. Singapore: Springer. https://doi. org/10.1007/978-981-13-2469-7_6

Zainal Amin Ayub, Harlida Abdul Wahab, Rohana Abdul Rahman, Aspalella A Rahman, Khadijah Mohamed, Haslinda Mohd Anuar and Che Thalbi Md Ismail. 2013. Tinjauan kerangka perundangan institusi pengajian tinggi Malaysia (Survey of legal framework of Malaysian higher education institutions). Paper presented at the 7th Universiti Utara Malaysia International Legal Conference, Kuala Lumpur, Malaysia, 13-14 November. 